\title{
SISTEM INFORMASI PELAYANAN DONATUR PADA KOMUNITAS 1000 GURU KALIMANTAN BARAT BERBASIS WEBSITE
}

\author{
Reza Maulana ${ }^{1}$, Yoki Firmansyah ${ }^{2}$, Hairil $^{3}$ \\ ${ }^{1,2,3}$ Universitas Bina Sarana Informatika Kampus Kota Pontianak \\ Jalan Abdurrahman Saleh No 18 A, Pontianak, 78124 \\ e-mail : reza.rza@bsi.ac.id ${ }^{1}$
}

\begin{abstract}
ABSTRAK
Komunitas 1000 Guru Kalimantan Barat merupakan salah satu cabang regional 1000 guru pusat yang telah terbentuk sejak 22 Agustus 2012. Komunitas ini terbentuk atas kepedulian masyarakat terhadap isu ketidakmerataannya pendidikan yang ada di pedalaman dan perbatasan Kalimantan Barat. Komunitas ini murni dibangun oleh relawan tanpa ada campur tangan pemerintah ataupun lembaga profit didalamnya, namun dalam perjalanannya terdapat beberapa kendala yang terjadi terutama pada masalah keuangan. Tercetuslah inisiatif untuk menggalang donasi, donasi yang dilakukan masih menggunakan cara konvensional dan belum tertata dengan baik, sehingga dirasa tidak maksimal. Selain itu, para donatur banyak yang ragu karena tidak bisa melihat berapa donasi dan kemana donasi mereka disalurkan, untuk mengatasi permasalahan tersebut maka dibuatlah sebuah sistem informasi yang dapat menyelesaikan permasalahan. Adapun sistem informasi donasi yang dibuat menggunakan berbasis website dengan menggunakan bahasa PHP dan menggunakan metode perancangan perangkat lunak waterfall yang menggunakan 4 tahapan yaitu analisa kebutuan, pembuatan desain, pengkodean, dan implementasi dan pengujian dengan metode black box, adapun hasil dari penelitian ini adalah sebuah sistem informasi berbasis website yang dapat mengelola data dan informasi dari donatur komunitas 1000 guru Kalimantan Barat.
\end{abstract}

Kata Kunci : Komunitas 1000 Guru Kalimantan Barat, Berbasis Web, Sistem Informasi Donasi

\begin{abstract}
The Community of 1000 West Borneo Teachers is one of the regional branches of 1000 central teachers that has been formed since August 22, 2012. This community was formed because of the community's concern over the issue of unequal education in the interior and borders of West Borneo. This community was built purely by volunteers without any interference from the government or profit institutions in it, but in its journey there were several obstacles that occurred mainly on financial matters. An initiative was initiated to raise donations, donations made were still using conventional methods and were not well organized, so it was felt to be not optimal. In addition, many donors were hesitant because they could not see how many donations were and where their donations were distributed, to overcome these problems an information system was created that could solve the problem. The donation information system that is made using website-based using PHP language and using the waterfall software design method that uses 4 stages, namely kebutuan analysis, design making, coding, and implementation and testing with the black box method, while the results of this study are a system website-based information that can manage data and information from the community donors of 1000 West Borneo teachers.
\end{abstract}

Keywords: 1000 West Borneo Teacher Community, Web Based, Donation Information

\section{PENDAHULUAN}

Komunitas 1000 Guru Kalimantan Barat merupakan komunitas yang didirikan pada tanggal 22 agustus 2012 pembentukan komunitas ini di Kalimantan Barat merupakan sebuah bentuk kepedulian terhadap isu ketidakmerataan pendidikan yang ada di pedalaman dan perbatasan Kalimantan Barat. Komunitas yang 
IN F ORMA TIK

Jurnal Informatika, Manajemen dan Komputer, Vol.11 No.2, Desember 2019

eISSN : 2580-3042

pISSN : 1979-0694

telah ada tiga tahun silam ini didirikan atas dasar keprihatinan anak bangsa, dan tanpa ada campur tangan pemerintahan maupun lembaga profit didalamnya. Salah satu program yang ada di 1000 Guru Kalimantan Barat yaitu Traveling and Teaching. Program traveling and teaching merupakan bentuk misi yang secara aktif megajak kalangan anak muda dari berbagai latar belakang prosfesi baik itu guru, dokter, presenter, mahasiswa dan lain-lain untuk ikut peduli terhadap pendidikan dengan memotivasi serta berbagi pengalaman dan ilmu pengetahuan kepada anak-anak usia sekolah yang ada di pedalaman maupun diperbatasan Kalimantan Barat. Program Traveling and Teaching ini telah dilaksanakan sebanyak tiga belas kali dimasingmasing sekolah yang berbeda diarea perbatasan Kalimantan Barat. Sebelum memulai program Traveling and Teaching, anggota 1000 Guru Kalimantan Barat menyelenggarakan open donation atau membuka donasi terbuka untuk merekrut calon donatur dan menerima donasi.

Menurut Dewantry (2015), "Donasi adalah suatu pemberian yang mempunyai sifat sukarela dengan tanpa adanya imbalan bersifat keuntungan, walaupun pemberian donasi dapat berupa makanan, barang, pakaian, mainan ataupun kendaraan akan tetapi tidak selalu demikian, pada peristiwa darurat bencana atau dalam keadaan tertentu lain". Sedangkan Menurut Kamus Besar Bahasa Indonesia (KBBI, 2016) Donasi adalah sumbangan tetap (berupa uang) dari penderma kepada perkumpulan.

Adapun proses penerimaan donasi dilaksanakan dengan cara calon donatur mentransferkan uang melalui via atm atau bank kepada nomor rekening yang telah ditentukan ataupun dengan cara calon donatur datang langsung ke sekretariat 1000 Guru Kalimantan Barat di Jl. Jambu Mente (Ruko CK Askrindo lantai 3), Jeruju, Pontianak.

1000 Guru Kalimantan Barat dalam melakukan proses donasi masih menggunakan cara yang konvensional dan belum belum tertata dengan baik dalam para donatur mendaftar, pengecekkan dari transferan ATM/Bank, pencatatan, perhitungan, maupun dalam pembuatan laporan belum tertata dengan rapi, hal tersebut menyebabkan proses donasi menjadi lama dan beberapa kendala terjadi seperti sulitnya mencari data donatur, merekap data donasi yang telah masuk serta sulitnya anggota 1000 Guru Kalimantan Barat membuat laporan hasil donasi sehingga memerlukan waktu yang lama, donatur tidak bisa melihat berapa donasi yang sudah mereka lakukan, donatur juga tidak

memiliki satu ruang tempat mereka saling berkoordinasi dan sulitnya para donatur untuk melihat laporan donasi.

Melihat permasalahan tersebut komunitas ini tentunya membutuhkan solusi yaitu dengan membuat sebuah sistem informasi berbasis website

Menurut (Hikmah et al,2015) dikutip dari bukunya Website merupkaan kumpulan halaman yang digunakan untuk menampilkan informasi dalam bentuk teks, gambar diam atau gerak, animasi, suara, dan/gabungan dari semuanya baik bersifat statis maupun dinamis yang membentuk suatu rangakaan yang saling terkait, yang masing masing dihubungan dengan jaringan jaringan halaman, sedangkan menurut (Abdulloh, 2016) website yang sering disingkat dengan web bisa diartikan sebagai sekumpulan halaman yang terdiri dari beberapa laman yang berisikan informasi dalam bentuk digital yang disediakan melalui jalur koneksi internet.

Sistem Informasi didefinisikan sebagai suatu alat untuk menyajikan informasi dengan cara sedemikian rupa sehingga bermanfaat bagi penerimanya menurut Kertahadi dalam (Risdiansyah, 2017).

Menurut Sutabri dalam (Handayani, Wijianto, \& Anggoro, 2018) menjelaskan bahwa Sistem Informasi adalah suatu sistem di dalam suatu organisasi yang mempertemukan kebutuhan pengolahan transaksi harian yang mendukung fungsi operasi organisasi bersifat manajerial dengan kegiatan strategi dari suatu organisasi untuk dapat menyediakan laporanlaporan yang diperlukan oleh pihak luar tertentu.

Tujuan dari penelitian ini adalah untuk memberikan kemudahan kepada para donatur dalam melakukan pendaftaran dan pengecekan donasi, serta mempermudah para anggota 1000 guru dalam mengecek dan merekap data donator sehingga laporan keuangan menjadi lebih transparan dan menjadikan komunitas ini lebih terpercaya dimata donatur

\section{METODOLOGI PENELITIAN}

Untuk mendukung penelitian ini penulis menggunakan 2 metode penelitian yaitu metode pengembangan perangkat lunak dan metode pengumpulan data adapun penjelasan dari masing masing metode tersebut adalah sebagai berikut :

a. Metode Pengumpulan Data

Metode ini dipergunakan untuk mengumpulkan data data yang terkait dengan penelitian.

- Observasi

Merupakan salah satu cara yang digunakan 


\section{IN F O RM A I K}

Jurnal Informatika, Manajemen dan Komputer, Vol.11 No.2, Desember 2019

elSSN : 2580-3042

pISSN : 1979-0694

untuk mendapatkan data, disini penulis langsung mendatangi lokasi dan mengamati apa yang terjadi pada objek penelitian, dan pada tahap ini pula penulis menemukan permasalahan bahwa yang menjadi permasalahan di komunitas 1000 Guru Kalimantan Barat adalah belum memiliki sebuah sistem informasi untuk mengelola donatur seperti yang penuliskan pada bagian sebelumnya

- Wawancara

Untuk memastikan permasalahan dan mencari solusi bersama dilakukan pula metode wawancara, dimana wawancara dilakukan langsung kepada Andy Kurniawan selaku ketua Komunitas 1000 Guru Kalimantan Barat, disini diketahui apa saja yang menjadi kebutuhan, dan penulis mendapatkan gambaran mengenai sistem informasi yang akan dibuat, baik dari sisi fungsional maupun non fungsional

- Studi Pustaka

Studi pustaka dilakukan untuk mencari teori teori yang terkait dengan penelitian, adapun literatur yang dipergunakan bersumber dari buku dan jurnal ilmiah

b. Metode Pengembangan Perangkat Lunak Metode yang penulis gunakan pada pengembangan perangkat lunak ini menggunakan tahapan model waterfall Sukamto dan Shalahuddin dalam (Firmansyah \& Udi, 2018) di jelaskan bahwa model waterfall sering juga disebut model sekuensi linear atau alur hidup klasik. Pengembangan sistem dikerjakan secara terurut mulai dari analisis, desain, pengkodean, pengujian dan tahap pendukung.

Analisa Kebutuhan

Pada tahap pertama ini, yang penulis lakukan adalah mengumpulkan kebutuhan-kebutuhan dari perangkat lunak yang akan dibangun melalui wawancara dan observasi langsung ke objek penelitian.

- Desain

Pada tahap kedua ini, yang penulis lakukan adalah mendesain atau merancang, adapun yang penulis rancang ERD (Entity Relationship Diagram) dan LRS (Logical Relational Structure) berserta komponenkomponennya seperti entitas, atribut, dan relasinya.

- Coding

Pada tahap pembuatan kode program, penulis menggunakan software Sublime Text 3, dan Xampp. Dengan Bahasa PHP dan database MySQL.

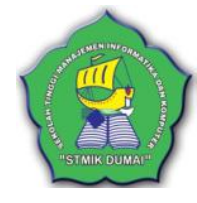

- Pengujian

Pada tahap ini, penulis menguji program yang sudah dibuat dengan pengujian Black Box memastikan bahwa semua fungsi berjalan dengan baik dan berjalan seperti yang diharapkan.

\section{HASIL DAN PEMBAHASAN}

Adapun yang menjadi hasil dari penelitian ini adalah sebuah Sistem Informasi yang ditujukan untuk mempermudah para donatur di komunitas 1000 Guru Kalimantan Barat yang dibuat dengan menggunakan metode waterfall adapun penerapan metode tersebut dalam membuat sistem informasi pelayanan donatur adalah sebagai berikut :

a. Analisa Kebutuhan Sistem

Analisa kebutuhan sistem didapat dari hasil observasi dan wawancara yang dilakukan di metode pengumpulan data, adapun hasil dari analisa ini yaitu sebagai berikut :

- Kebutuhan Fungsional

Kebutuhan fungsional merupakan langkah awal dalam membuat sebuah software atau website, adapun kebutuhan fungsional dari website pelayanan donatur adalah sebagai berikut :

1. Kebutuhan Admin (Bendahara)

a. Dapat login dan mengubah password admin.

b. Mengolah pendaftaran calon donatur.

c. Menerima bukti transaksi yang masuk.

d. Mengelola daftar rekening, termasuk menambah, megubah data, dan meghapus rekening.

e. Admin bisa mencetak laporan.

2. Kebutuhan Donatur

a. Dapat daftar.

b. Dapat login.

c. Memilih rekening pembayaran.

d. Mengunggah bukti pembayaran

e. Melihat berita donasi.

f. Melihat informasi organisasi.

- Kebutuhan Non Fungsional

Dalam menjalankan sebuah sistem tentunya dibutuhkan perankat pendukung agar sistem dapat berjalan dengan lancar.

1. Perangkat Keras (Hardwere)

Perangkat keras minimum yang dibutuhkan antara lain:

a. Processor : Intel (R) Celeron (R) CPU 847.

b. Penyimpanan : 2,00 GB.

c. RAM : 2048 RAM.

d. Mouse, Keyboard, Printer.

2. Perangkat Lunak (Softwere) 
IN F ORMA T I K A

Jurnal Informatika, Manajemen dan Komputer, Vol.11 No.2, Desember 2019

eISSN : 2580-3042

pISSN : 1979-0694

Perangkat lunak yang dibutuhkan antara lain:
a. Operating system.
b. Web server : Apache/2.4.39, PHP 7.1.30.
c. Database server : MySQL 10.1.38- MARIADB.
d. Text Editor: Sublime Text.
e. Web Browser : Google Chrome, Mozilla FireFox, Microsoft Edge.

b. Desain

Tahap desain merupakan tahapan kedua dimana ditahap ini penulis menerjemahkan kebutuhan fungsional kedalam diagram dan tampilan aplikasi, adapun hasilnya yaitu sebagai berikut:

a. Desain ERD

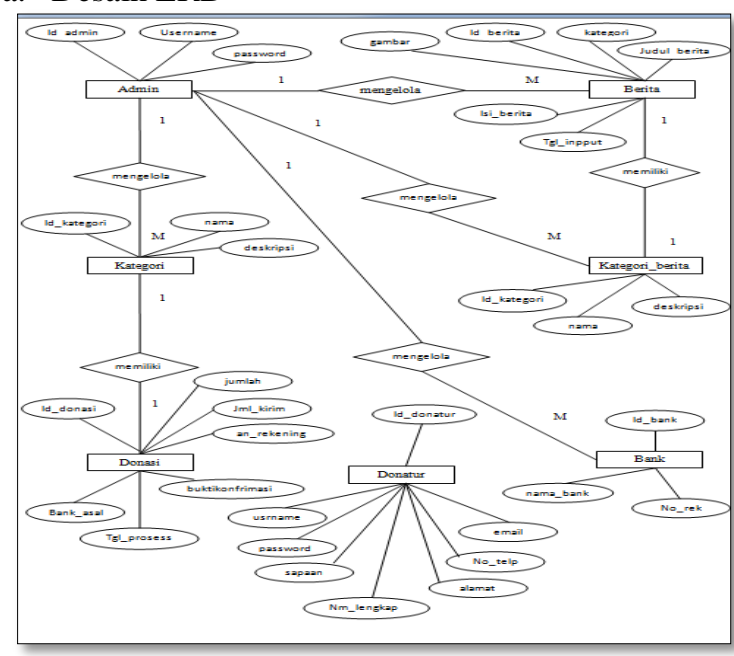

Gambar 1. ERD Sistem informasi Pelayanan Donatur

b. Desain LRS

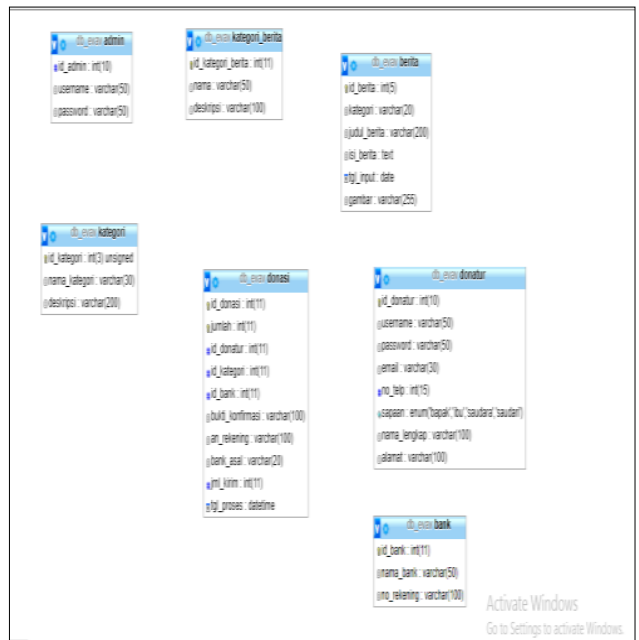

Gambar 2. Desain LRS Sistem Informasi Pelayanan Donatur c. Rancangan Struktur Navigasi

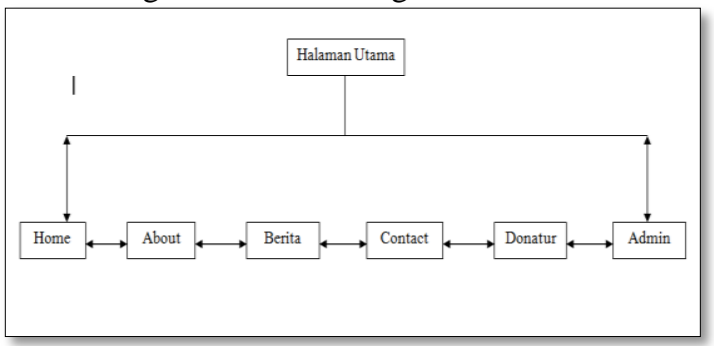

Gambar 3. Struktur Navigasi Haman Utama

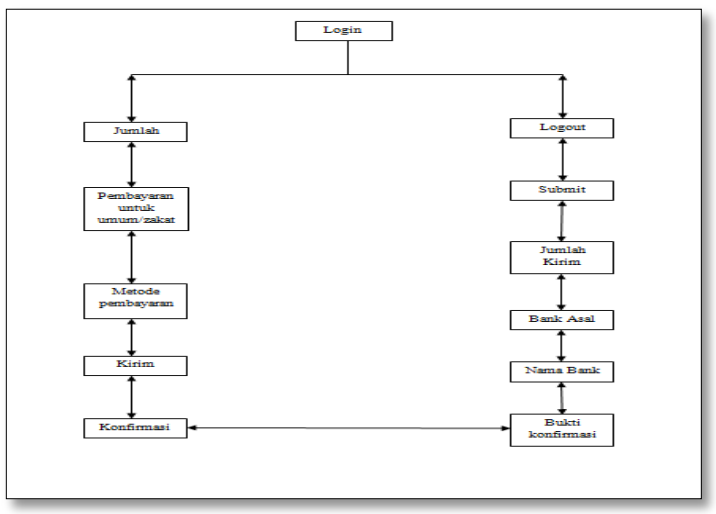

Gambar 4. Struktur Navigasi Donatur

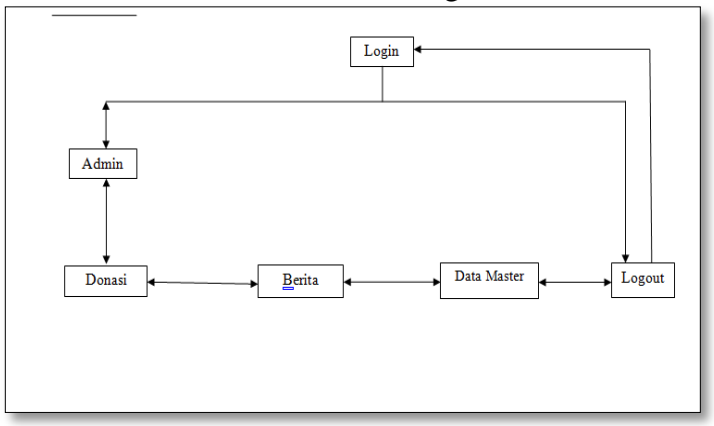

Gambar 5. Struktur Navigasi Admin

c. Pengkodean / Implementasi

Hasil analisa kebutuhan dan rancangan diimplementasikan dalam bentuk kode-kode yang diubah menjadi sebuah halaman website, adapun hasil implementasi dari website donasi 1000 Guru Kalimantan Barat adalah sebagai berikut :

a. Tampilan Halaman Menu Utama

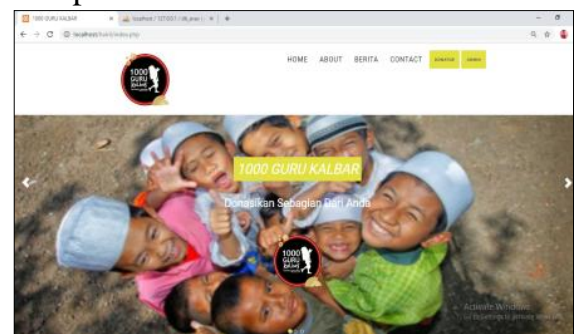

Gambar 6. Tampilan Utama Pengunjung / Donatur 
IN F ORMA T I K A

Jurnal Informatika, Manajemen dan Komputer, Vol.11 No.2, Desember 2019

eISSN : 2580-3042

pISSN : 1979-0694

b. Halaman Pendaftaran Calon Donatur

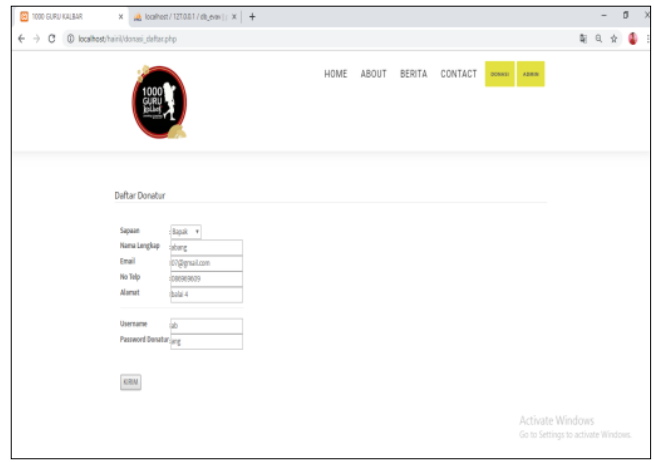

Gambar 7. Halaman Pendaftaran Calon Donatur

c. Halaman Login Donatur

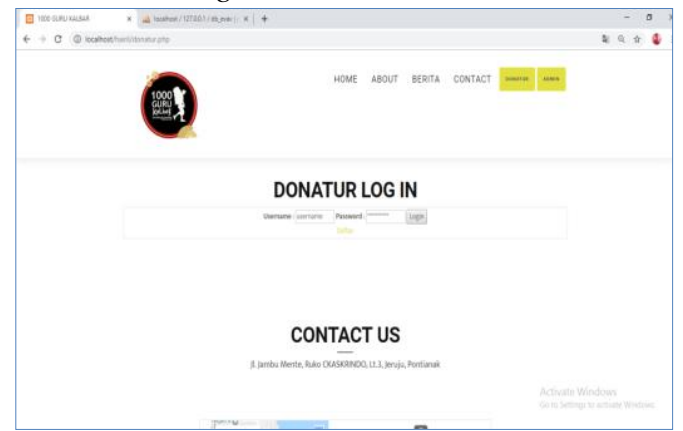

Gambar 8. Halaman Login Donatur

d. Tampilan Halaman Donatur

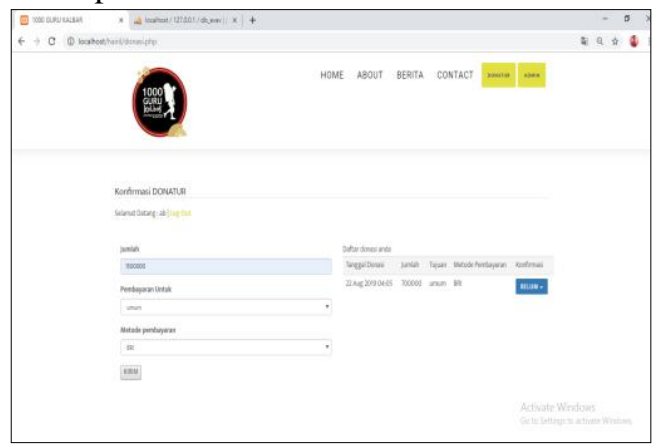

Gambar 9. Halaman Utama Donatur

e. Halaman Upload Struk Donasi

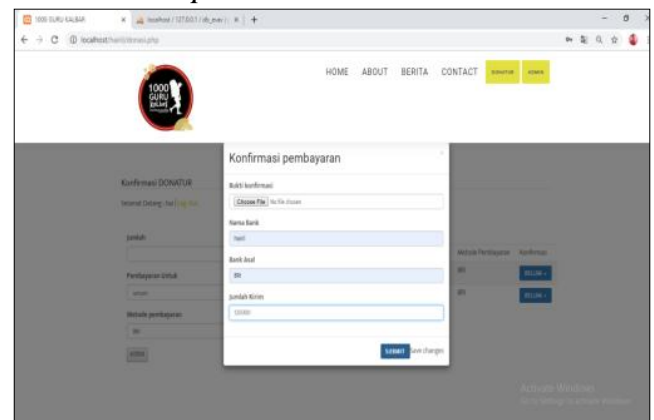

Gambar 10. Halaman Upload Struk Donasi f. Halaman Login Admin

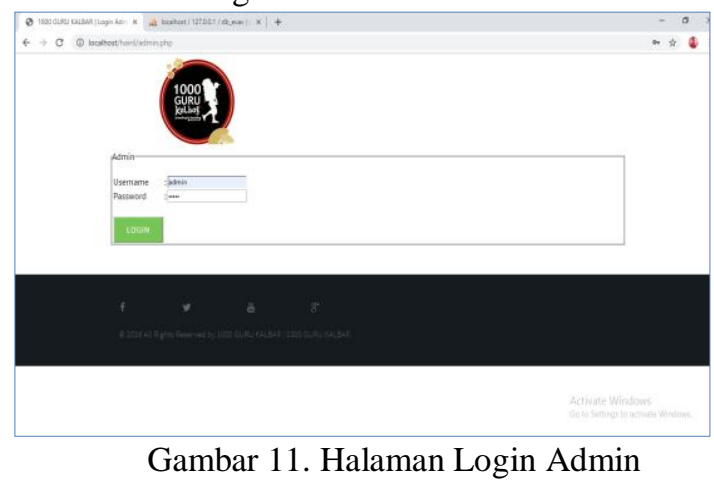

g. Halaman utama Admin

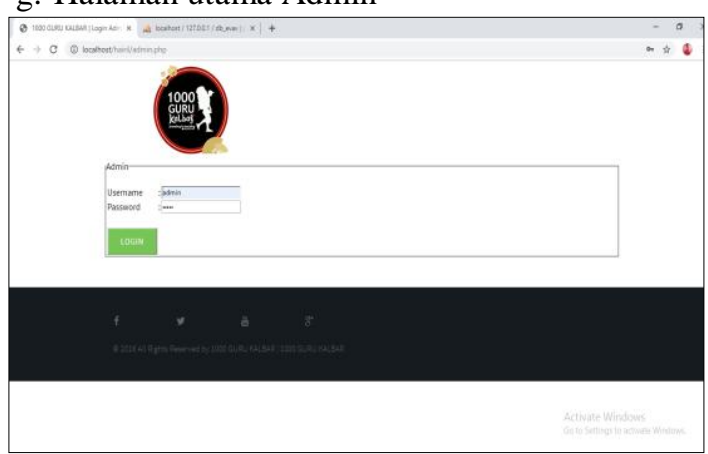

Gambar 12. Halaman utama Admin

d. Pengujian

Setelah tahap pengkodean di lakukan, maka berikutnya adalah dilakukan Uji pada aplikasi sistem informasi tersebut, adapun pengujian dilakukan dengan metode blackbox testing.

Black box testing merupakan pengujian yang memungkinkan software engineer mendapatkan serangkaian kondisi input yang sepenuhnya menggunakan semua persyaratan fungsional untuk suatu program dalam (Schumann et al., 2015). Sedangkan menurut Menurut Sommerville dalam (Ardhana, 2016) "Proses black-box testing adalah pengujian yang berasal dari spesifikasi sistem. Sistem diperlakukan seperti sebuah kotak hitam (blackbox) yang mana perilaku hanya bisa ditentukan dengan mempelajari inputan dan keluaran yang berhubungan".

Adapun hasil dari pengujian menggunakan blackbox testing pada sistem informasi Pelayanan donatur adalah sebagai berikut : 
IN F ORMA T I K A

Jurnal Informatika, Manajemen dan Komputer, Vol.11 No.2, Desember 2019

eISSN : 2580-3042

pISSN : 1979-0694

a. Pengujian terhadap Form Login Admin

Tabel 1. Uji Black Box Form Login Admin

\begin{tabular}{|c|c|c|c|c|c|}
\hline No & $\begin{array}{c}\text { Skenario } \\
\text { pengujian }\end{array}$ & Test Case & $\begin{array}{l}\text { Hasil yang } \\
\text { diharapkan }\end{array}$ & $\begin{array}{c}\text { Hasil } \\
\text { pengujian }\end{array}$ & Kesimpulan \\
\hline 1 & $\begin{array}{l}\text { Username dan } \\
\text { password tidak } \\
\text { diisi kemudian } \\
\text { tekan tombol } \\
\text { login }\end{array}$ & $\begin{array}{l}\text { username: } \\
\text { (kosong) } \\
\text { Password: } \\
\text { (kosong) }\end{array}$ & $\begin{array}{l}\text { Sistem menolak } \\
\text { akses dan } \\
\text { menampilkan } \\
\text { pesan "Username } \\
\text { atau password } \\
\text { salah" }\end{array}$ & $\begin{array}{l}\text { Sesuai } \\
\text { Harapan }\end{array}$ & Valid \\
\hline 2 & $\begin{array}{l}\text { Username diisi } \\
\text { dan password } \\
\text { dikosongkan, } \\
\text { kemudian tekan } \\
\text { login }\end{array}$ & $\begin{array}{l}\text { username } \\
\text { : admin } \\
\text { password: } \\
\text { (kosong) }\end{array}$ & $\begin{array}{l}\text { Sistem menolak } \\
\text { akses dan } \\
\text { menampilkan } \\
\text { pesan "Username } \\
\text { atau password" }\end{array}$ & $\begin{array}{c}\text { Sesuai } \\
\text { Harapan }\end{array}$ & Valid \\
\hline 3 & $\begin{array}{l}\text { Mengetikan } \\
\text { username dan } \\
\text { password } \\
\text { dengan data } \\
\text { yang benar } \\
\text { kemudian klik } \\
\text { login } \\
\end{array}$ & $\begin{array}{l}\text { username: } \\
\text { admin } \\
\text { (benar) } \\
\text { password: } \\
\text { admin } \\
\text { (benar) }\end{array}$ & $\begin{array}{l}\text { Sistem menerima } \\
\text { akses login dan } \\
\text { menampilkan } \\
\text { menu halaman } \\
\text { utama. }\end{array}$ & $\begin{array}{l}\text { Sesuain } \\
\text { Harapan }\end{array}$ & Valid \\
\hline
\end{tabular}

b. Pengujian terhadap Form Edit Admin

Tabel 2. Pengujian Black Box Edit Admin

\begin{tabular}{|c|c|c|c|c|c|}
\hline No & $\begin{array}{c}\text { Skenario } \\
\text { pengujian }\end{array}$ & Test Case & $\begin{array}{c}\text { Hasil yang } \\
\text { diharapkan }\end{array}$ & $\begin{array}{c}\text { Hasil } \\
\text { pengujian }\end{array}$ & Kesimpulan \\
\hline 1 & $\begin{array}{c}\text { Semua data } \\
\text { dikosongkan } \\
\text { ketika } \\
\text { mengupdate } \\
\text { data admin }\end{array}$ & $\begin{array}{c}\text { Data } \\
\text { kosong. } \\
\text { akses dan } \\
\text { menampilkan } \\
\text { pesan } \\
\text { "username(kosong) } \\
\text { dan password: } \\
\text { (kosong)". }\end{array}$ & $\begin{array}{c}\text { Sesuai } \\
\text { harapan }\end{array}$ & Valid \\
\hline & $\begin{array}{c}\text { Mengisi semua } \\
\text { data, di admin } \\
\text { page,dan klik } \\
\text { update }\end{array}$ & $\begin{array}{c}\text { Username } \\
\text { : hairil } \\
\text { Password: } \\
\text { hairil }\end{array}$ & $\begin{array}{c}\text { Sistem menerima } \\
\text { dan menyimpan } \\
\text { data }\end{array}$ & $\begin{array}{c}\text { Sesuai } \\
\text { harapan }\end{array}$ & Valid \\
\hline
\end{tabular}

c. Pengujian Terhadap Form Tambah Berita

Tabel 3. Pengujian Black Box Tambah Berita

\begin{tabular}{|c|c|c|c|c|c|}
\hline $\mathrm{N}_{0}$ & $\begin{array}{l}\text { Skenario } \\
\text { pengujian }\end{array}$ & Test Case & $\begin{array}{c}\text { Hasil yang } \\
\text { diharapkan }\end{array}$ & $\begin{array}{c}\text { Hasil } \\
\text { pengujian }\end{array}$ & Kesimpulan \\
\hline 1 & $\begin{array}{l}\text { Semua data } \\
\text { dikosongkan }\end{array}$ & Data kosong. & $\begin{array}{c}\text { Sistem } \\
\text { menolak } \\
\text { akses dan } \\
\text { menampilkan } \\
\text { pesan "data } \\
\text { tidak boleh } \\
\text { kosong". }\end{array}$ & $\begin{array}{l}\text { Sesuai } \\
\text { harapan }\end{array}$ & Valid \\
\hline 2 & $\begin{array}{c}\text { Mengisi } \\
\text { semua data } \\
\text { dengan benar }\end{array}$ & $\begin{array}{c}\text { Mengisi data } \\
\text { dengan lengkap dan } \\
\text { benar }\end{array}$ & $\begin{array}{l}\text { Sistem } \\
\text { menerima } \\
\text { dan } \\
\text { menyimpan } \\
\text { data }\end{array}$ & $\begin{array}{l}\text { Sesuai } \\
\text { harapan }\end{array}$ & Valid \\
\hline
\end{tabular}

d. Pengujian Terhadap Form Kelola Bank

Tabel 4. Pengujian Blackbox Kelola Bank

\begin{tabular}{|c|c|c|c|c|c|}
\hline No & $\begin{array}{l}\text { Skenario } \\
\text { pengujian }\end{array}$ & Test Case & $\begin{array}{l}\text { Hasil yang } \\
\text { diharapkan }\end{array}$ & $\begin{array}{c}\text { Hasil } \\
\text { pengujian }\end{array}$ & Kesimpulan \\
\hline 1 & $\begin{array}{l}\text { Semua data } \\
\text { dikosongkan }\end{array}$ & Data kosong. & $\begin{array}{c}\text { Sistem } \\
\text { menolak } \\
\text { akses dan } \\
\text { menampilkan } \\
\text { pesan } \\
\text { "please fill } \\
\text { out this } \\
\text { field". }\end{array}$ & $\begin{array}{c}\text { Sesuai } \\
\text { harapan }\end{array}$ & Valid \\
\hline 2 & $\begin{array}{c}\text { Mengisi } \\
\text { semua data } \\
\text { dengan benar }\end{array}$ & $\begin{array}{c}\text { Mengisi data } \\
\text { dengan lengkap dan } \\
\text { benar }\end{array}$ & $\begin{array}{c}\text { Sistem } \\
\text { menerima } \\
\text { dan } \\
\text { menyimpan } \\
\text { data }\end{array}$ & $\begin{array}{c}\text { Sesuai } \\
\text { harapan }\end{array}$ & Valid \\
\hline 3 & $\begin{array}{c}\text { Mengubah } \\
\text { sebuah data } \\
\text { dengan benar }\end{array}$ & $\begin{array}{c}\text { Mengisi data } \\
\text { dengan lengkap dan } \\
\text { benar }\end{array}$ & $\begin{array}{c}\text { Sistem } \\
\text { menerima } \\
\text { dan } \\
\text { menyimpan } \\
\text { data yang } \\
\text { telah diubah }\end{array}$ & $\begin{array}{c}\text { Sesuai } \\
\text { harapan }\end{array}$ & Valid \\
\hline
\end{tabular}

e. Pengujian terhadap Form Kelola Kategori Donasi

Tabel 5. Pengujian Blackbox Kelola Donasi

\begin{tabular}{|c|c|c|c|c|c|}
\hline No & $\begin{array}{l}\text { Skenario } \\
\text { pengujian }\end{array}$ & Test Case & $\begin{array}{l}\text { Hasil yang } \\
\text { diharapkan }\end{array}$ & $\begin{array}{c}\text { Hasil } \\
\text { pengujian }\end{array}$ & Kesimpulan \\
\hline 1 & $\begin{array}{l}\text { Semua data } \\
\text { dikosongkan }\end{array}$ & Data kosong. & $\begin{array}{c}\text { Sistem } \\
\text { menolak } \\
\text { akses dan } \\
\text { menampilkan } \\
\text { pesan } \\
\text { "please fill } \\
\text { out this } \\
\text { field". }\end{array}$ & $\begin{array}{c}\text { Sesuai } \\
\text { harapan }\end{array}$ & Valid \\
\hline 2 & $\begin{array}{c}\text { Mengubah } \\
\text { semua data } \\
\text { dengan benar }\end{array}$ & $\begin{array}{c}\text { Mengisi data } \\
\text { dengan lengkap dan } \\
\text { benar }\end{array}$ & $\begin{array}{c}\text { Sistem } \\
\text { menerima } \\
\text { dan } \\
\text { menyimpan } \\
\text { data yang } \\
\text { telah diubah }\end{array}$ & $\begin{array}{c}\text { Sesuai } \\
\text { harapan }\end{array}$ & Valid \\
\hline
\end{tabular}

f. Pengujian terhadap Form Pendaftaran Calon Donatur

Tabel 6. Pengujian Blackbox Pendaftaran Calon Donatur

\begin{tabular}{|c|c|c|c|c|c|}
\hline No & $\begin{array}{c}\text { Skenario } \\
\text { pengujian }\end{array}$ & Test Case & $\begin{array}{l}\text { Hasil yang } \\
\text { diharapkan }\end{array}$ & $\begin{array}{c}\text { Hasil } \\
\text { pengujian }\end{array}$ & Kesimpulan \\
\hline 1 & $\begin{array}{l}\text { Semua data } \\
\text { dikosongkan }\end{array}$ & Data kosong. & $\begin{array}{c}\text { Sistem } \\
\text { menolak } \\
\text { akses dan } \\
\text { menampilkan } \\
\text { pesan } \\
\text { "please fill } \\
\text { out this } \\
\text { field". }\end{array}$ & $\begin{array}{c}\text { Sesuai } \\
\text { harapan }\end{array}$ & Valid \\
\hline 2 & $\begin{array}{c}\text { Mengisi } \\
\text { semua data } \\
\text { dengan benar }\end{array}$ & $\begin{array}{c}\text { Mengisi data } \\
\text { dengan lengkap dan } \\
\text { benar }\end{array}$ & $\begin{array}{c}\text { Sistem } \\
\text { menerima } \\
\text { dan } \\
\text { menyimpan } \\
\text { data } \\
\text { pendaftaran }\end{array}$ & $\begin{array}{c}\text { Sesuai } \\
\text { harapan }\end{array}$ & Valid \\
\hline
\end{tabular}


IN F ORMA T I K A

Jurnal Informatika, Manajemen dan Komputer, Vol.11 No.2, Desember 2019

eISSN : 2580-3042

pISSN : 1979-0694

g. Pengujian Terhadap Form Konfirmasi Donatur

Teknologi \& Manajemen Informatika, 4(1), 184-191.

Tabel 7. Pengujian Blackbox Konfirmasi

Donatur

\begin{tabular}{|c|c|c|c|c|c|}
\hline No & $\begin{array}{l}\text { Skenario } \\
\text { pengujian }\end{array}$ & Test Case & $\begin{array}{l}\text { Hasil yang } \\
\text { diharapkan }\end{array}$ & $\begin{array}{c}\text { Hasil } \\
\text { pengujian }\end{array}$ & Kesimpulan \\
\hline 1 & $\begin{array}{l}\text { Semua data } \\
\text { dikosongkan }\end{array}$ & Data kosong. & \begin{tabular}{|c|} 
Sistem \\
menolak \\
akses dan \\
menampilkan \\
pesan \\
"please fill \\
out this \\
field". \\
\end{tabular} & $\begin{array}{r}\text { Sesuai } \\
\text { harapan }\end{array}$ & Valid \\
\hline 2 & $\begin{array}{l}\text { Mengo songkan } \\
\text { isian data } \\
\text { jumlah donasi. } \\
\text { Lalu langsung } \\
\text { klik tombol } \\
\text { kirim. }\end{array}$ & $\begin{array}{l}\text { Jumlah: (kosong) } \\
\text { Pembayaran } \\
\text { untuk: (umum) } \\
\text { Metode } \\
\text { pembayaran:BRI) }\end{array}$ & \begin{tabular}{|c|} 
Sistem \\
menolak \\
akses dan \\
menampillan \\
pesan "data \\
gagal \\
diproses \\
silahkan \\
coba lagi".
\end{tabular} & $\begin{array}{l}\text { Sesuai } \\
\text { harapan }\end{array}$ & Valid \\
\hline 3 & $\begin{array}{c}\text { Mengisi semua } \\
\text { data dengan } \\
\text { benar }\end{array}$ & $\begin{array}{l}\text { Mengisi data } \\
\text { dengan lengkap } \\
\text { dan benar }\end{array}$ & $\begin{array}{c}\text { Sistem } \\
\text { menerima } \\
\text { dan } \\
\text { menyimpan } \\
\text { data dan } \\
\text { menampillan } \\
\text { pesan "data } \\
\text { berhasil } \\
\text { disimpan". }\end{array}$ & $\begin{array}{c}\text { Sesuai } \\
\text { harapan }\end{array}$ & Valid \\
\hline
\end{tabular}

Handayani, V. R., Wijianto, R., \& Anggoro, A. (2018). Sistem Informasi Pendaftaran Seleksi Kerja Berbasis Web Pada Bkk (Bursa Kerja Khusus) Tunas Insan Karya Smk Negeri 2 Banyumas 1. Jurnal Evolusi, 6(1), 76-84.

Hikmah, A. baitul, Supriadi, D., \& Bina Sarana Informatika. (2015). Cara Cepat Membangun Website dari Nol: Studi Kasus: Web Dealer Motor. Yogyakarta: CV. Andi Offset.

Risdiansyah, D. (2017). Perancangan Sistem Informasi Bimbingan Konseling Berbasis Desktop pada SMA Kemala Bhayangkari 1 Kubu Raya Deni. Khatulistiwa Informatika, 5(2), 86-91.

Schumann, S. A., Schimelpfenig, T., Sibthorp, J., Collins, R. H., HATZAKIS, K. D., KRITSOTAKIS, E. I., ... Calvet, B. (2015). 春秋發微言 戰國繞辯論No Title. In Safety Science (Vol. 33). https://doi.org/10.1016/j.ssci.2015.04.023

\section{KESIMPULAN}

Kesimpulan yang didapat dari penelitian ini yaitu

- Dengan adanya sistem informasi ini maka akan mempermudah calon para donatur untuk melakukan pendaftaran

- Dengan adanya sistem informasi ini maka akan mempermudah donatur dalam pengecekan donasi

- Dengan sistem informasi anggota 1000 Guru Kalimantan Barat dapat lebih mudah mengecek data dan donasi dari para donatur

- Sistem informasi yang dibuat memudahkan komunitas 1000 Guru Kalimantan Barat dalam merekap donasi yang diberikan oleh para donatur

- Sistem informasi yang dibuat dapat menghasilkan laporan yang lebih baik dibandingkan dengan cara lama yang biasa digunakan oleh komunitas 1000 Guru Kalimantan Barat

\section{REFERENSI}

Abdulloh, R. (2016). Easy \& Simple - Web Programming. Jakarta: Elex Media Computindo.

Ardhana. (2016). Bab ii landasan teori 2.1. Bsi, 14-31.

Firmansyah, Y., \& Udi. (2018). Penerapan Metode SDLC Waterfall Dalam Pembuatan Sistem Informasi Akademik. Jurnal 